\title{
NUTRIENT STOCKS IN FOUR STAGES OF A LOWLAND RAIN FOREST AT PASIRMAYANG, JAMBI, CENTRAL SUMATRA, INDONESIA
}

\author{
PAMUJI LESTARI \\ Faculty of Agriculture, University of Bengkulu, Bengkulu, Sumatra, Indonesia
}

\begin{abstract}
Studies of nutrient cycling of tropical forests should differentiate between dynamic stages of the forest. We studied the nutrient concentration ( $, \mathrm{P}, \mathrm{K}, \mathrm{Ca}$ and $\mathrm{Mg}$ ) and phytomass of aboveground (living and non living parts) and belowground compartments (soil) in four dynamic stages, namely Building (Bl and $\mathrm{B} 2$ ), and Mature (Ml and M2) stages, for a lowland rain forest.

Nutrient concentrations in various compartments differed between the dynamic stages. Bark contains higher nutrient concentration than wood parts, both in stems and branches. Leaves contain higher nutrient concentration than wood parts, both in litterfall and litter. The concentration of $\mathrm{K}$ in throughfall is the highest, $\mathrm{Ca}$ and $\mathrm{Mg}$ perform similar value. Throughfall exhibits lower nutrient concentration than open area rain water. The nutrient concentration of $10-20 \mathrm{~cm}$ is higher than in the $0-10 \mathrm{~cm}$ soil depth.

The phytomass values are highly variable among tree parts, diameter classes and dynamic stages. The phytomass is generally the highest in M2 and significantly different from Bl, Ml and B2. The phytomass of leaves in litterfall and litter is higher than wood parts. More litterfall and litter are accumulated in mature than building phases.
\end{abstract}

Key words : nutrient / phytomass / dynamics / rain / forest

\section{INTRODUCTION}

Understanding the cycling of the original forest ecosystem mineral nutrients is essential in evaluating consequences of forest replacement to agriculture, tree plantations, or best methods by which forests can be managed for sustained timber production.

Reviews of overall patterns of mineral cycling in the tropics (Jordan 1985; Vitousek and Sanford 1986; Proctor 1987; Bruijnzeel 1989) clearly show a wide diversity. The tropical rain forests are very rich in species with large interspecific differences in chemical composition (Grubb and Edwards 1982; Hobie 1992), and they differ in species competition and structure over sometimes short distances (Trichon 1996). Moreover, the tropical forests are very dynamic systems, mosaic of regenerating and mature "phases" (Halle et al. 1978; Whitmore 1984). This invariably rises the question of the representativeness of field samples that are always small for obvious logistic reasons, when extrapolating the data to the whole ecosystem.

The present study is part of a wider research program on nutrient patterns and variability in tropical forested lowland landscapes, both accross physiographical and 
successional gradients in Jambi province, Sumatra. It was initiated not only because there is so little information available on productivity (Soerianegara 1966; Schaik and Mirmanto 1985) and nutrient cycling (Soedjito 1988; Strigel et al. 1993) of rain forest in Indonesia in general, but also because the understanding of the variability of nutrient availability in such forested landscape is needed for forest land management. This study was conducted to determine whether nutrient stocks and phytomass significantly vary among dynamic stages and how the nutrient maintains the rain forest ecosystems.

\section{SITE DESCRIPTION}

The Pasirmayang permanent plot in the Jambi province of Sumatra $\left(1^{\circ} 5\right.$ 'S latitude and $102^{\circ} 10^{\prime} E$ longitude, North Muarabungo city) offers an excellent opportunity to study lowland rain forest function and dynamics since topography is very gentle, meaning that there are no or few interaction between dynamics and slopes.

Average altitude varies between 70 and 100 in and the plot's physiography is gentle with slopes ranging from 2 to $8 \%$ for drops of 5 to $30 \mathrm{~m}$.

The underlying geology is that of vast Tertiary deposition basins mainly formed in sedimentary rock. These geological formations consist of layers several kilometers thick and mainly include sandstones, calcareous sandstone and marls.

The soils encountered in the plot are mainly Oxisols. The A horizon, located at a depth of 2 to $10 \mathrm{~cm}$, contains a superficial fine root layer, and its low organic content is a characteristic feature (C/N from 8 to 15). Clay content increases with depth (A-B located between 10 and $40 \mathrm{~cm}$ ). Kaolinite sensu stricto accounts for at least $80 \%$ of the clay fraction and the low loam/clay ratio is characteristic. In the brown or yellow-brown B horizon, soil acidity remains relatively constant ( $\mathrm{pH}$ between 4 and 5). The cation exchange capacity is very low, less than 15 meq/lOOg of clay. These soils rank amongst the least fertile and are extremely fragile once forest has been cleared (erosion on slopes, compacting by heavy vehicles, insolation and rapid loss of surface minerals). Few changes in soil characteristics are observed between the lower slopes and the top of the ridges in the plot.

The litter is mostly very thin and covers a humus horizon of 2 to $3 \mathrm{~cm}$ thick, sometimes $15 \mathrm{~cm}$ deep from place to place. These thicker layers are related to dominance of certain species like Dipterocarpus crinitus or D. lowii whose leaves apparently decompose very slowly. The humus horizon is extremely acid in these instances (pH 3.8 to 4). 
In general, the climate of the area shows an annual rainfall between 200 and $2500 \mathrm{~mm}$ /year. Monthly mean rainfall can drop below $100 \mathrm{~mm}$ for one month at most, and the yearly average of rainy days varies from 120 to 150, with a mean temperature of the coldest month always above $20^{\circ} \mathrm{C}$. However, as indicated by Laumonier (1995) climatic variability is high and rather long dry periods (2 to 3 months) can be experienced for some years.

The forest is a typical lowland Dipterocarp forest as described for the eastern Sumatra plains by Laumonier (1995).

\section{MATERIALS AND METHODS}

\section{A. FIELD SAMPLING}

\section{A.I. Sampling Unit Selection in Relation to Forest Dynamics}

Following previous research on forest dynamics in that area by Torquebiau (1986) and Laumonier (1991), several criteria were taken into account for the selection of what can be seen as representative of mature and "old" building forest phases. For the particular purpose of the study a former classification of the forest dynamics made by Laumonier (op.cit), was combined with Whitmore (1984) tree diameter classes for mature, building and gap phases, and refined using vertical and horizontal structure criteria e.g :

- frequency histogram for diameters and heights,

- scatter and profile diagrams,

- crown projection, canopy cover, crown overlapping,

- treefall gaps

and added with a concept by Halle et al. (1978) that classifies trees according to their architecture: 1) Trees of the "Future" which are represented by the first stage of development when either conform to their original model or are regenerated by reiteration, 2) Trees of the "Present" are trees that survive from earlier phase of development, show no regeneration in an architectural sense as a whole and have established a new energetic balance, and 3) Trees of the "Past" are trees that show no particular response to the outside energy, facing an architectural chaos from disturbance and are gradually eliminated.

A total of eight plots assigned in four dynamic stages with two replications in each dynamic stage were used to evaluate those vertical and structural criteria. 


\section{A.2. Vegetation and Soil Sampling}

\section{a. Nutrient Concentration}

In each plot (20 m x $20 \mathrm{~m}$ ), aboveground compartments as living parts (leaves, stems, branches and twigs), non living parts (litterfall, litter, and throughfall) and belowground (soil) compartments were sampled for the nutrients that are most likely to limit primary production and other ecosystem function (N, P, K, Ca and Mg).

\section{a.l. Aboveground Compartments}

Living Parts (Trees)

Trees were sampled for three stem diameter classes $30 \mathrm{~cm}$ and up (all diameter higher than $30 \mathrm{~cm}$ which vary among plots), 010-29.99 cm and 0 3-9.99 cm. A composite of leaves, stems (wood, bark), branches (wood, bark), and twigs from five trees in each of the three diameter class was collected for each plot of various dynamic stages obtained from the structural analysis. An approximate of 0.5-1 kg of leaves, branches and twigs were obtained by cutting, whereas samples of stems were obtained by slashing the main stems to reduce tree damage.

Non Living Parts

\section{- Litterfall}

Two semi-permanent circular litter traps (diameter $1 \mathrm{~m}$ ) were used for litterfall collections. They were equipped with plastic mesh $1.25 \mathrm{~m}$ above the ground to allow proper water drainage. At emptying, the contents of each trap were put in a paper bag and sorted into leaves and woody parts. There is a total of 32 samples (8 plots; two replications in each stage with two litterfall traps in each plot and two different parts; leaves and wood).

\section{- Litter}

Two litter samples (one square meter each) were taken from every plot. A total of 32 samples both for leaves and woody parts were analyzed.

\section{- Throughfall}

A total of seventeen water samples were collected for nutrient analysis. Two plastic drums with a polyethylene funnel of diameter $22.5 \mathrm{~cm}$ in every plot were 
used for throughfall collection. An additional drum was put in the open for sampling bulk precipitation.

\section{a, 2 Belowground (Soil)}

A metal ring of $8.5 \mathrm{~cm}$ diameter and $10 \mathrm{~cm}$ height was used for soil collection. A total of 32 soil samples (two samples in every plot at two soil depths: 0$10 \mathrm{~cm}$ and $10-20 \mathrm{~cm}$ ) were used for nutrient analysis.

Roots were not included in the present study due to logistic reason.

\section{b. Phytomass}

\section{Living Parts (Trees)}

The phytomass of living parts in the three diameter classes has been estimated from allometric equations developed by Yamakura et al. (1986) who studied plant biomass with reference to forest dynamics in East Kalimantan (Table 1) The phytomass calculation was based on the number of trees in each plot according to diameter classes. The results of 8 plots were then averaged and presented in each dynamic stage.

Table 1. Regression equation for calculating biomass of tree parts developed by Yamakura (1986)

\begin{tabular}{|c|c|}
\hline Tree & Regression Equation \\
\hline $\begin{array}{l}\text { Stem biomass (sb) } \\
\text { Branch biomass (bb) }\end{array}$ & $\begin{array}{c}2.903 \times 10^{\prime \prime 2}\left(\mathrm{D}^{2} \mathrm{H}\right)^{\circ 9833} \\
\text { i } 259\end{array}$ \\
\hline Leaf biomass (Ib) & 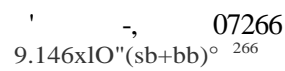 \\
\hline
\end{tabular}

$\mathrm{Sb}, \mathrm{bb}, \mathrm{Ib}$, in $\mathrm{kg} \mathrm{D}$

(Diameter) in $\mathrm{cm} \mathrm{H}$

(Height) in $\mathrm{m}$

Non Living Parts

\section{- $\quad$ Litterfall}

The equipments used are the ones used for sampling the litterfall for nutrient concentration study. The litterfall phytomass obtained is the $\mathrm{g} / \mathrm{m}^{2}$ of samples dry weight and extrapolated into ton/ha. 


\section{- $\quad$ Litter}

The litter phytomass was obtained from the dry weight inside a square meter subplot (g/m), then it was extrapolated into ton/ha.

\section{B. LABORATORY ANALYSIS}

Prior to nutrient analysis, above ground and below ground materials were oven dried at $105^{\circ} \mathrm{C}$ for 48 hours or until constant weight. After determining oven dry weight, the samples were ground and nutrient analyzed.

Total nitrogen was determined using Kjeldahl digestion and distillation method and Phosphorus was analyzed using Spectrophotometry. An Atomic Absorption spectrophotometer was used for Potassium and Calcium analysis, whereas Magnesium was determined by using Flame Photometer.

\section{DATA ANALYSIS}

The nutrient concentration of different parts of trees, litterfall, litter and soil in various dynamics were compared using Least Significant Difference (LSD) of the Statistix Program Package version 4.0 (Siegel 1992).

\section{RESULTS AND DISCUSSION}

\section{A. STRUCTURAL AND DYNAMIC CLASSIFICATION OF THE PLOTS}

The height of the forest canopy varies from 30 to $40 \mathrm{~m}$ with emergent trees rising to heights of 45 to $55 \mathrm{~m}$. Mature phase of the forest may have up to four distinct foliage mass layer respectively, situated at the following heights: 5 to 10 (15), 15 - 20(25), 25 30(35), and 35 - 40(45) m (Laumonier 1995).

A total of eight plots were selected representing mature phases and building phases (Figure la - b) following the former classification by Laumonier (1991). Eventhough it is important to study the early stages of succession i.e. treefall gaps and young aggrading phases to complete the comparison of each dynamic stage, they were excluded from the study due to logistic reasons. 
Building 1
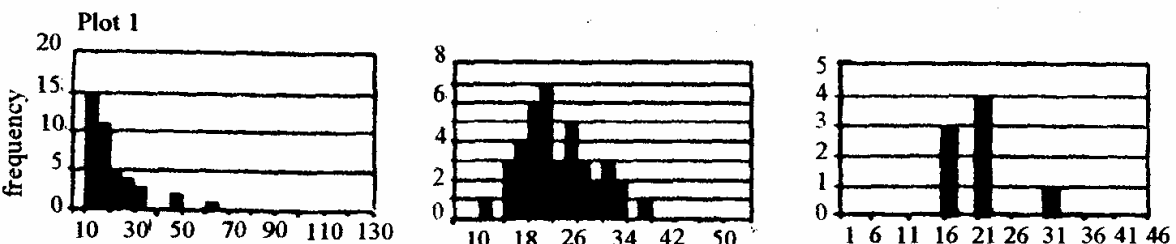

Plot 2
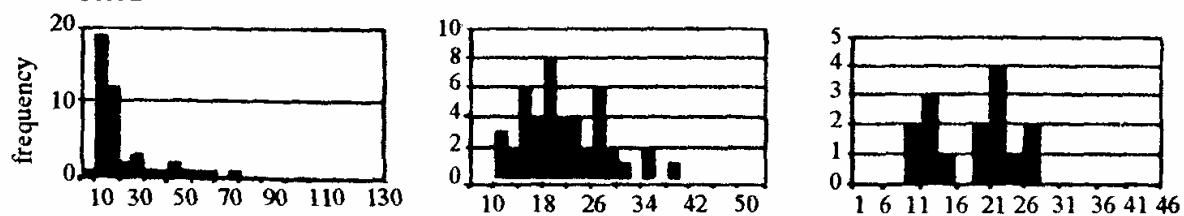

Building 2
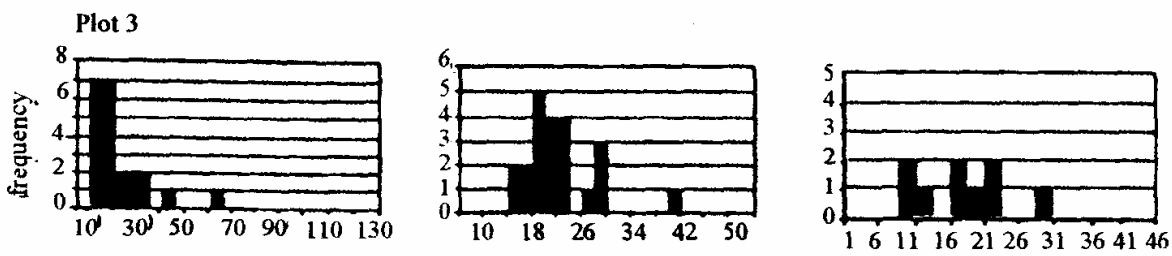

Plot 4
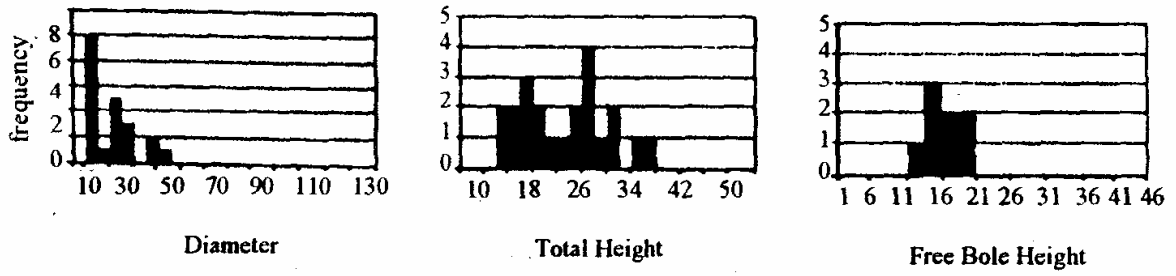

Figure 1a. Structural and vertical comparison of old building plots in Pasirmayang. 
Nutrient Stock in Four Stages of a Lowland Rain Forest at Pasirmayang, Jambi - Pamuji Lestari

Mature 1

Plot 5
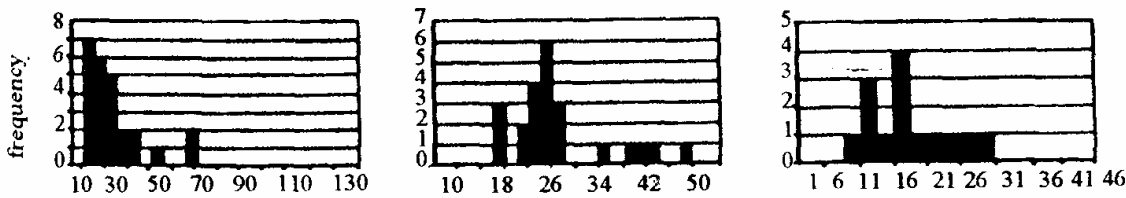

Plot 6
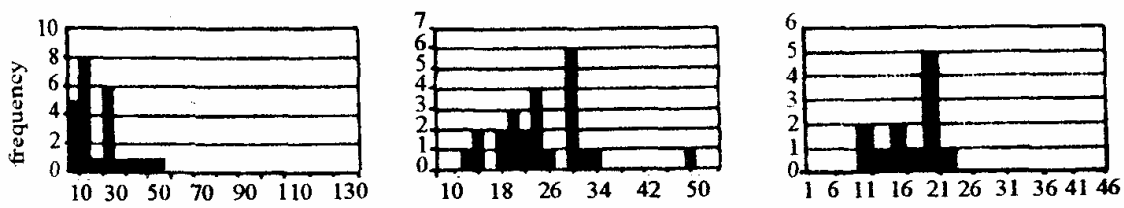

Mature 2
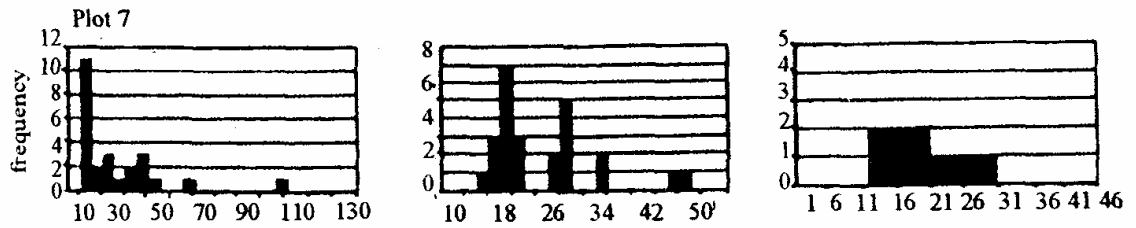

Plot 8
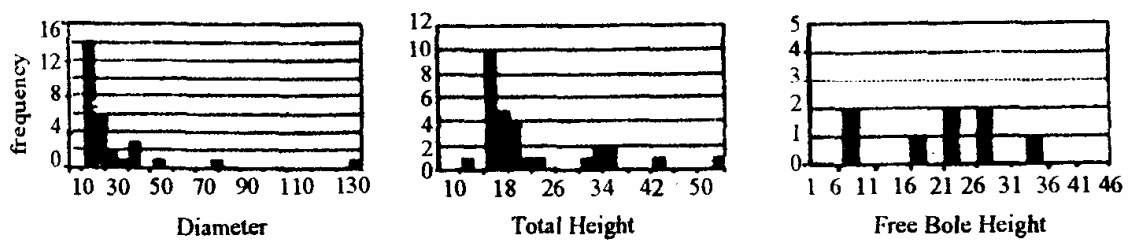

Figure $\mathrm{lb}$. Structural and vertical comparison of mature plots in Pasirmayang. 
As shown in Table 2, further analysis of the horizontal structure of these plots (number of trees, diameter, height, basal area, abundance, dominance and canopy cover), allows to group them into 4 classes corresponding to four dynamical status situation. Building 1 (Bl), Building 2 (B2), Mature 1 (Ml), and Mature 2 (M2).

The number of trees in the four different classes are not significantly different except for B2 where a high tree density is observed. In all plots, the density is always higher for trees of the Future, with the exception of Ml where abundance of trees of the Present is conspicuous. The trees of the Past are the most abundant in M2.

Total, covered and overlap crown surface are the highest in Bl followed by M2, $\mathrm{Ml}$ and B2, whereas gap surface is the highest for B2 followed by $\mathrm{Ml}, \mathrm{M} 2$ and $\mathrm{Bl}$. In term of coverage, the horizontal structure is always dominated by "The trees of the Present" (M1>M2>B2>B1) followed by "Trees of the Future" (B2>B1>M2>M1) and "Past Trees" (B1>M1>B2>M2). Average basal area of the four different classes is similar, but more variations are observed in the vertical structure and the respective arrangement of the tree classes (Table 2).

\section{B. NUTRIENT CONCENTRATION}

The complete results of nutrient concentration in various compartments (tree, litterfall, litter, throughfall and soil) are presented in Figure 2a - d.

\section{B.I. Aboveground}

\section{a. Living Parts (Trees)}

The general pattern of nutrient concentration in trees observed in this forest is $\mathrm{N}$ $>\mathrm{K}>\mathrm{Ca}>\mathrm{Mg}>\mathrm{P}$. Mostly $\mathrm{N}$ concentration in leaves is the highest compared to other parts This condition is mainly due to the physiological role of the leaves in photosynthetic activity. Other nutrient concentrations are varied among parts. Barks which play considerable role in transferring nutrients from trees into soil are always present in higher nutrient concentration than sap wood, both in stems and branches.

\section{b. Non Living Parts}

\section{b. 1. Litterfall}

Most nutrient concentration is varied between parts and among dynamics. The variable nutrient concentration in litterfall may be mainly the result of water penetration versus leaching from rainfall, influenced by the position of leaves in the trees, and also by the species composition. The higher nutrient concentration of 


\section{Nutrient Stock in Four Stages of a Lowland Rain Forest at Pasirmayang. Jambi - Pamuji Lestari}

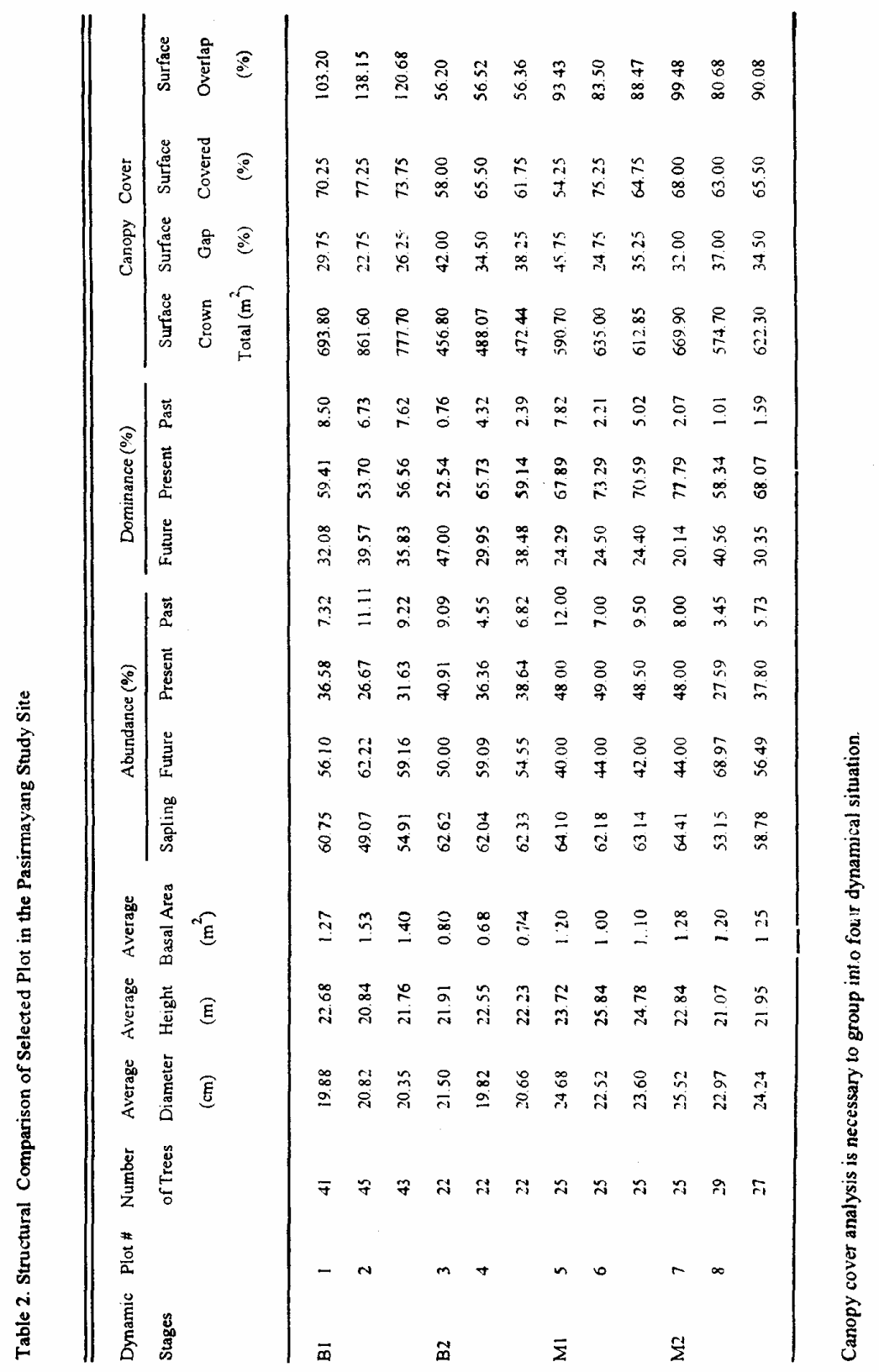


BIOTROPIA No. 11, 1998

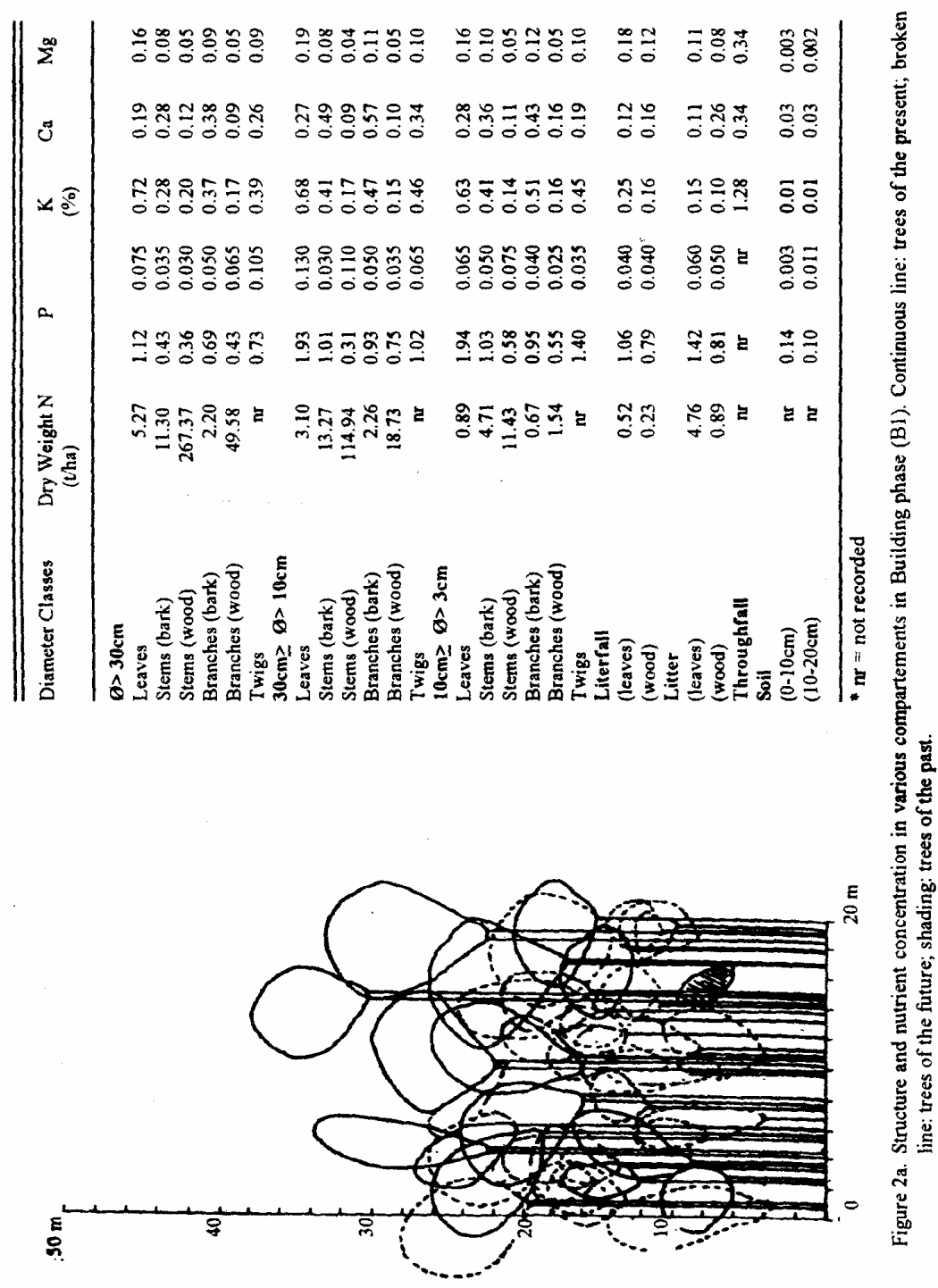


Nutrient Stock in Four Stages of a Lowland Rain Forest at Pasirmayang, Jambi - Pamuji Lestari

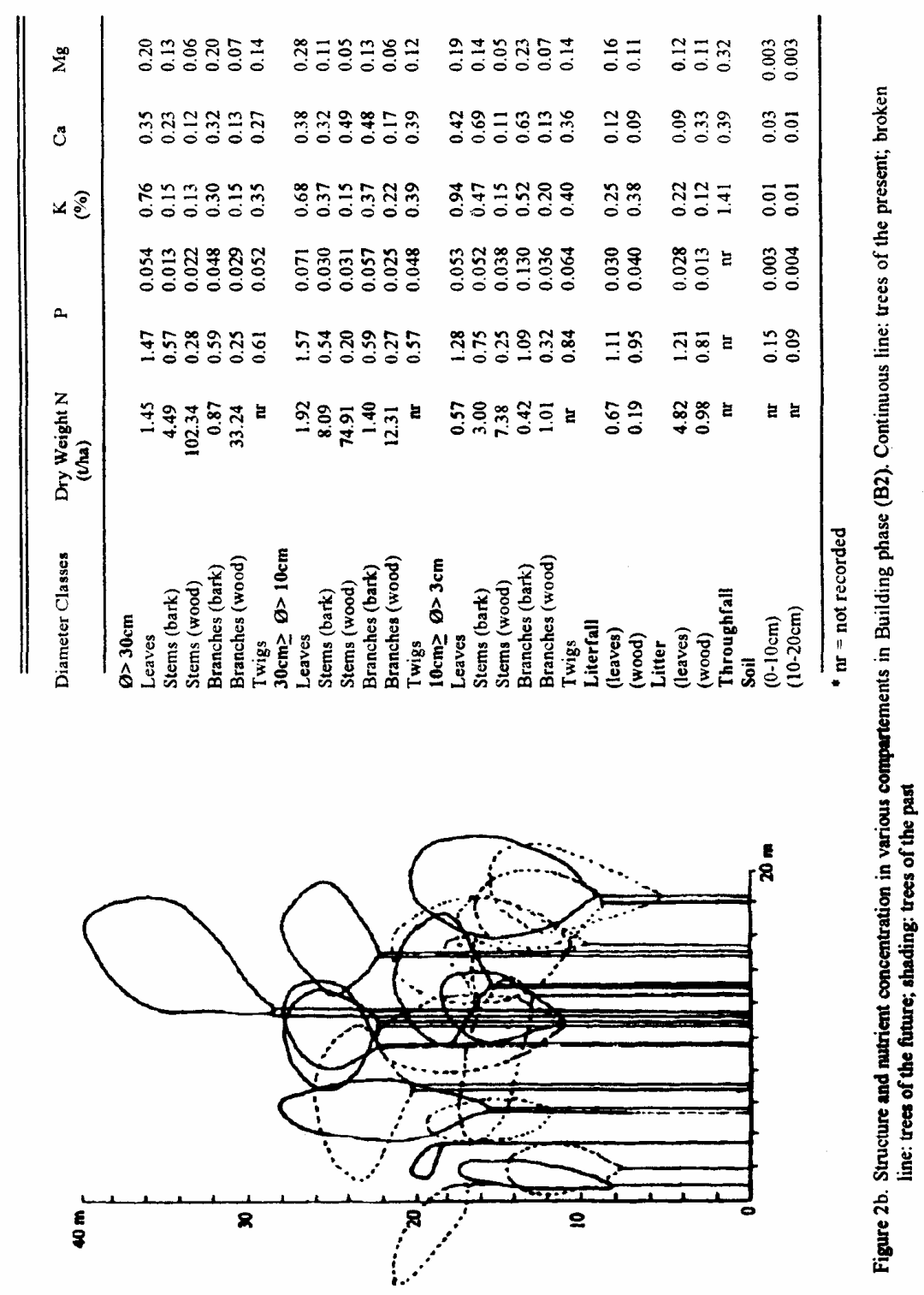




\section{BlOTROPIA No. 11, 1998}
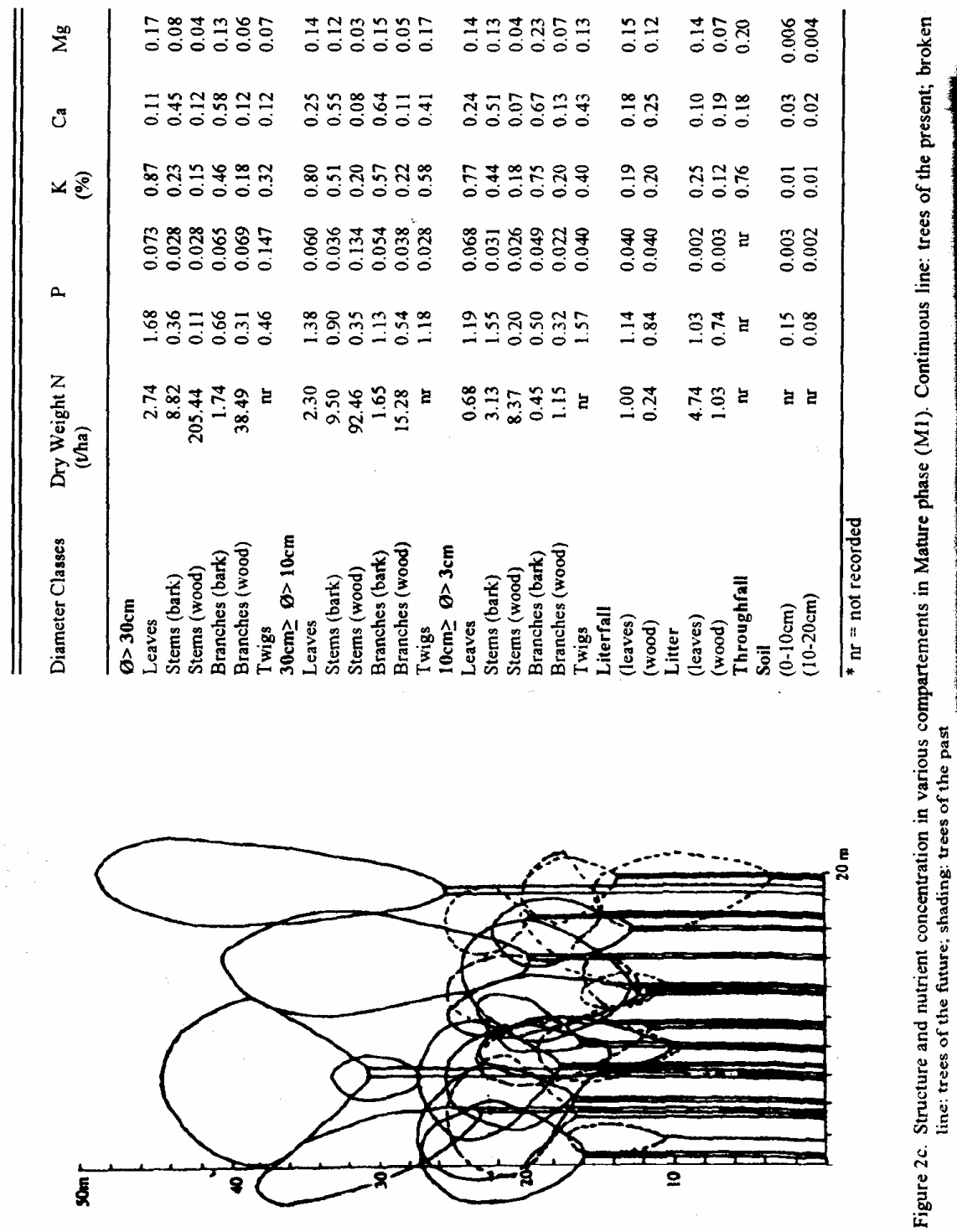
Nutrient Stock in Four Stages of a Lowland Rain Forest at Pasirmayang, Jambi - Pamuji Lestari
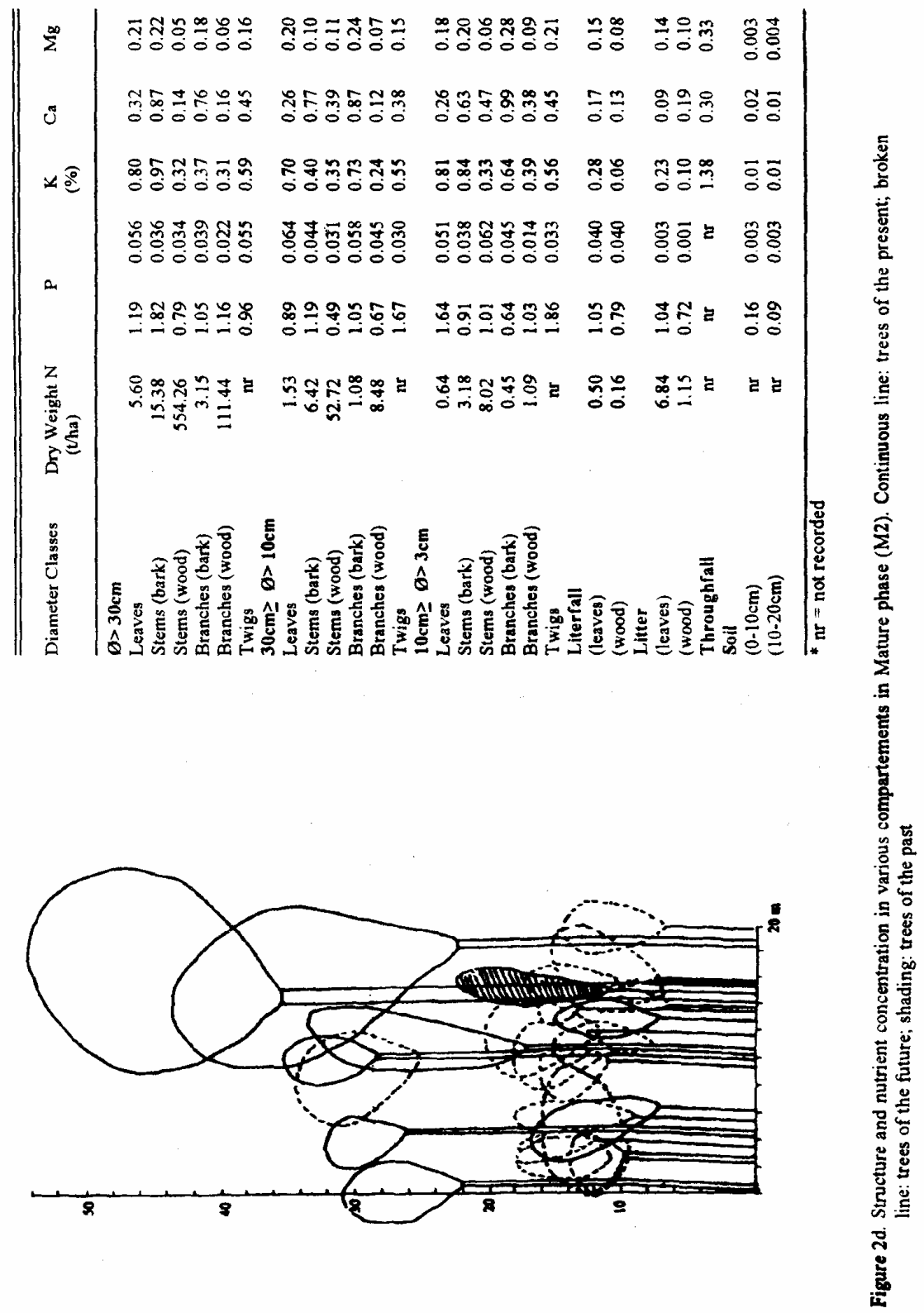
leaves and wood parts in building phase may be due to the condition that in this stage plants are very active in uptaking and storing nutrients from soil.

\section{b.2. Litter}

All nutrients in both parts are not significantly different among dynamics. The concentration of $\mathrm{N}, \mathrm{K}$ and $\mathrm{Ca}$ of leaves is significantly different from wood parts. Similar to litterfall, the nutrient concentration of leaves is higher than wood parts, litter concentrates higher nutrients in building than mature stages.

The fallen leaves are accumulated as forest litter. Thus, the nutrient concentration of the litter may mainly come from the concentration of the forming materials. Therefore, the higher nutrient concentration of the litterfall may result in the higher nutrients in the litter. Moreover, in the process of decomposition more nutrients will become available, and so the concentration of nutrients in litter may be increased.

By comparing aboveground living parts, it shows that the nutrient contents in leaves $>$ litterfall $>$ litter. The average percentage of four dynamic stages in nutrient withdrawal before litterfall is the highest for K (68\%) followed by P (46\%), Ca (42\%), N (24\%) and Mg (12\%). The poorer quality of litter compared to litterfall may suggest that the process of decomposition is very slow.

\section{b.3. Throughfall}

In the four phases, $\mathrm{K}$ exhibits the highest concentration both as input (open area) and throughfall in the forest ecosystem, whereas Ca and Mg show similar values. This result agrees to that of Manokaran (1980) that the nutrient concentration increased as precipitation passed through the canopy as throughfall due to leaching at the canopy with conspicuous amount for $\mathrm{K}$, relatively less for $\mathrm{Mg}$ and $\mathrm{Ca}$.

The average nutrient concentration of throughfall is higher in building than mature stage. This may be caused by the higher surface covered in building than mature stage that allows more water penetration after reaching the canopy.

The values of $\mathrm{Ca}$ and $\mathrm{Mg}$ in the Pasirmayang forest are lower than that obtained in open area. This is in contrast with Strigel et al. (1993) who studied the nutrient concentration of throughfall in two forest sites in East Kalimantan (Table 3 ). 
Table 3. The nutrient concentration (mg/1) of throughfall in Pasirmayang, Sumatra vs Bukit Suharto and Lempake, East Kalimantan

\begin{tabular}{lccccccc} 
& \multicolumn{3}{c}{ Throughfall } & \multicolumn{3}{c}{ Open } \\
& & $\mathrm{K}$ & $\mathrm{Ca}$ & $\mathrm{Mg}$ & $\mathrm{K}$ & $\mathrm{Ca}$ & $\mathrm{Mg}$ \\
Pasimayang (BPH) & 1.21 & & 0.30 & 0.30 & 1.33 & 0.41 & 0.30 \\
Bukit Suharto & 1.80 & & 0.40 & 0.05 & 0.10 & 0.20 & 0.02 \\
Lempake & 1.70 & & 0.60 & 0.08 & 0.30 & 0.20 & 0.02
\end{tabular}

In Pasirmayang, the nutrient concentration of open area is higher than in throughfall, although they are not significantly different. This condition may be due to the water sample collectors'position in the open area of Pasirmayang (20 m X 20 m plot size) that may still be affected by leaching of nearby canopy, i.e. increasing the nutrient concentration. In bukit Suharto and Lempake, the nutrient concentration of throughfall is higher than in the open area. This phenomenon may be the result of the water sampling position that is far from the forest area (100 m apart), therefore the effect of adjacent trees could be avoided.

\section{B.2. Bcltm ground (Soil)}

The concentration of $\mathrm{P}$ and $\mathrm{Ca}$ is not significantly different between depths in all stages. Other nutrients are varied. All nutrient concentrations are not significantly different among dynamics.

At 0-10 cm soil depth, the pattern of nutrient concentration in old building (B2) and mature phase (M2) is similar with $\mathrm{N}>\mathrm{Ca}>\mathrm{K}>\mathrm{P}$ or Mg. However, some differences in nutrient concentration of top soil among dynamics were observed among the plots.

At 10-20 cm depth, the pattern of nutrient concentration is similar to that at $0-10$ cm with $\mathrm{N}>\mathrm{Ca}>\mathrm{K}>\mathrm{P}$ or Mg.

The $\mathrm{P}$ in both soil depths are generally limited because of the small mass circulation in most forests, small input from atmosphere to compensate losses from available pools and fixation by Fe and $\mathrm{Al}$ oxides in highly weathered acid soil.

The concentration of nutrients is higher in top than in the lower layer. This may be the result of higher litter decomposition process above the top soil that releases many nutrients to the soil.

Apparently, the concentration of nutrients in the soil of the building phase was higher than that of the mature phase. Knowing, however, the extremely high variability of soil nutrient availability in the rain forest environment, it may be difficult to draw conclusions. The relationship between forest dynamics with soil 
variation pattern is a very complex phenomenon which is difficult to assert within the present study.

\section{PHYTOMASS}

\section{C.I. Living Parts (Trees)}

The general aboveground phytomass for the entire Pasirmayang plot varies between 320 and 400 ton of dry matter per hectare (Laumonier 1991) for trees with a diameter $>10 \mathrm{~cm}$. Undergrowth samples provide a further estimate of 15 to 20 ton/ha for individuals with a diameter ranging from 3 to $10 \mathrm{~cm}$.

At an average of 30 to $40 \mathrm{~kg} / \mathrm{m}^{2}$ (extremes being 0 to $80 \mathrm{~kg} / \mathrm{m}^{2}$ ), epigeal phytomass varies from 2.65 to 30.7 ton $/ 400 \mathrm{~m}^{2}$. In the selected plots, the phytomass pattern of trees in different diameter classes $(0>30 \mathrm{~cm}, 10<0<30 \mathrm{~cm}$ and $3<0<$ $10 \mathrm{~cm}$ ) and dynamic stages is shown in Figure 3a - c. Among the plots, the general phytomass pattern for living parts is $\mathrm{M} 2>\mathrm{Bl}>\mathrm{Ml}>\mathrm{B} 2$. M2 stage exhibits the highest phytomass and differs significantly from $\mathrm{Ml}$, B2 and $\mathrm{Bl}$.

For the diameter class $10<0<30 \mathrm{~cm}$ alone, $\mathrm{Bl}>\mathrm{Ml}>\mathrm{B} 2>\mathrm{M} 2 . \mathrm{Bl}$ is the type of dynamic stage where fierce competition exists between a large number of "future" trees reaching the canopy.

The phytomass in the $3<0<10 \mathrm{~cm}$ diameter class performs similar to that of pole trees with $\mathrm{Bl}$ exhibiting the highest followed by Ml, M2 and B2.

\section{C.2. Non Living Parts}

\section{a. Litter/all}

As shown in Fig. 4a, in all stages, leaves litterfall phytomass is higher than wood litterfall. The pattern of total litterfall and leaves litterfall is $\mathrm{Ml}>\mathrm{B} 2>\mathrm{Bl}>$ M2, whereas for wood litterfall, the pattern is slightly different with $\mathrm{Bl}>\mathrm{B} 2>\mathrm{Ml}>$ M2.

\section{$b$ Litter}

Regarding Utter accumulated on the ground, the pattern of leaves and total litter is the highest in M2 followed by $\mathrm{B} 2, \mathrm{Ml}$ or $\mathrm{Bl}$ (Fig. 4b). In woody litter, the phytomass of mature is higher than in building stages. This phenomenon seems to correspond to a natural succcssional pattern of forest dynamics from building to mature phase, the "older" the phase, the more litter accumulated 
Nutrient Stock in Four Stages of a Lowland Rain Forest at Pasirmayang, Jambi - Pamuji Lestari

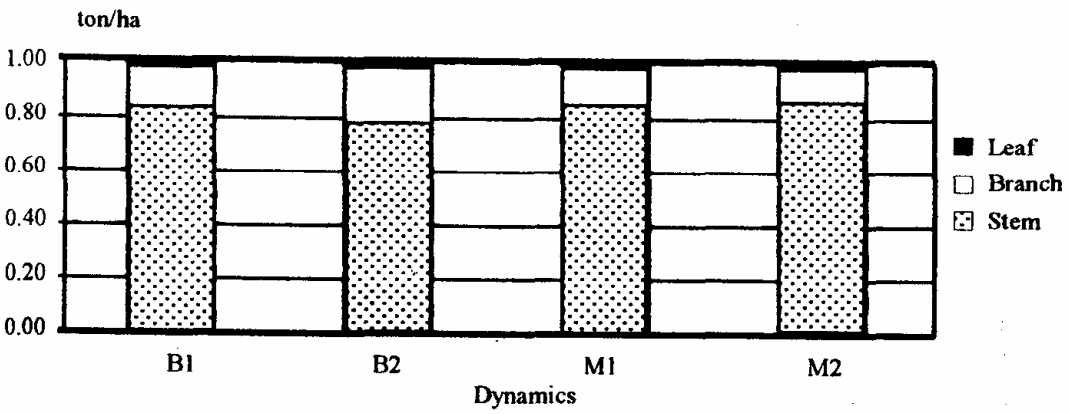

Figure 3a. Phytomass of trees $(\theta>30 \mathrm{~cm})$

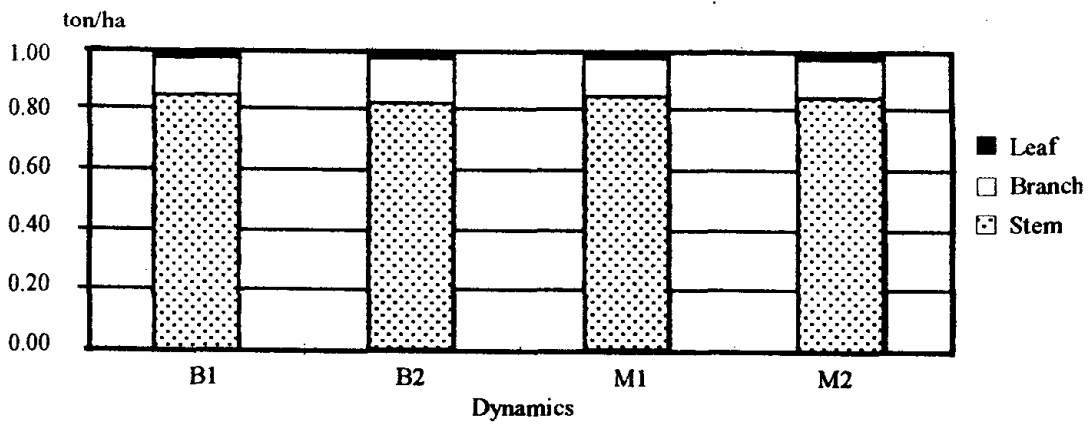

Figure 3b. Phytomass of trees $(O>10-29.99 \mathrm{~cm})$

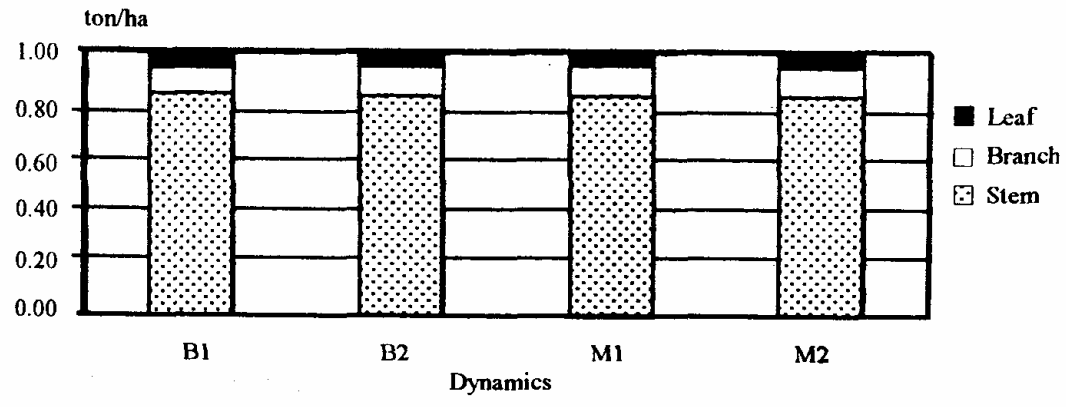

Figure $3 \mathrm{c}$. Phytomass of trees $(\theta>3-9.99 \mathrm{~cm})$ 


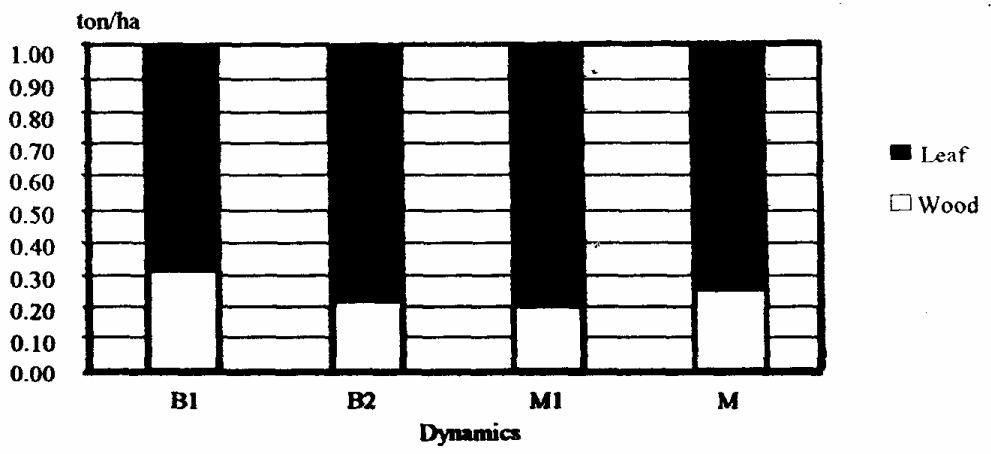

Figure 42. Phytomass of limerfall

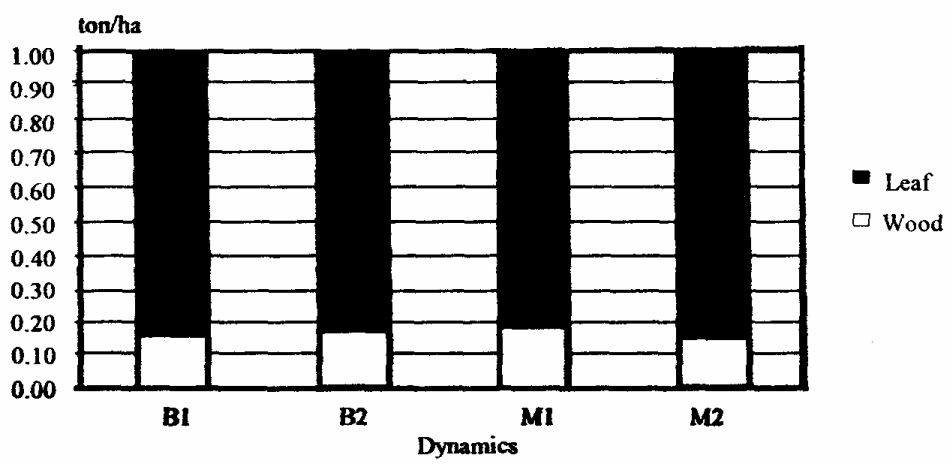

Figure 4b. Phytomass of litter

\section{CONCLUSION}

The present study shows that there is no significant difference in the nutrient stock between building and mature stages. However, the nutrient concentration is highly variable among various parts of trees, in ground litter and soil compartments that may suggest the importance of species composition and the diversity of top soil nutrient pattern.

Mature phase generally performs the highest biomass of trees, litterfall and litter which relates to the successional stages. 
Nutrient Stock in Four Stages of a Lowland Rain Forest at Pasirmayang, Jambi - Pamuji Lestari

\section{REFERENCES}

BRUUNZEEL, L.A. 1989. Moist tropical forest nutrient cycling : the hydrological framework. In Proctor, J. (ed). Mineral nutrienU in tropical forest and savana ecosystems, p. 383-416.

GRUBB, P.J AND P.J. EDWARDS. 1982. Studies of mineral cycling in a montane rain forest in New Guinea. III. The distribution of mineral elements in the aboveground material. Journal of Ecology 70:623-648.

HALLE, F.R., A.A. Oldeman and P.B. Tomlinson 1978. Tropical Trees and Forests. Springer-Verlag, Heidelberg.

HOBBIE, S.E. 1992. Effects of plant species on nutrient cycling. Tree7(10):336-339.

JORDAN, C.F. 1985. Nutrient cycling in tropical forest ecosystems. Wiley. London.

LAUMONffiR, Y. 1991. Vegetation de Sumatra, Indonesia . ecologie, flore, phytogeographie. Th Doct. Etat, UPS Toulouse, France. 337p.

LAUMONIER, Y. 1995. The vegetation and physiography of Sumatra. Geobotany 22. Kliiwer Academic, Dordrecht, $234 \mathrm{p}$.

MANOKARAN, N. 1980. The nurient contents of precipitation, throughfall and stemfiow in a lowland tropical rain forest in Peninsular Malaysia. The Malaysian Forester 43(3):266-289.

PROCTOR, J. 1987. Nutrient cycling in primary and old secondary forest. Applied Geography 7:135-152.

SCHADC, C.P. VAN AND E. MKMANTO. 1985. Spatial variation in the structure and litter production in a Sumatran rain forest. Biotropica 17:196-205.

SIEGEL, J. 1992. Statistix version 4. Analytical Software. Borland International Inc. and Fleming Software. Minnesota, USA.

SOERIANEGARA, I. 1966. The primary productivity of selected forests in Indonesia. Rimba Indon. 10(4):246-256.

SOEDIITO, H. 1988. Spatial pattern, biomass, and nutrient concentrations of root systems in primary and secondary forest trees of a tropical rainforest in Kalimantan, Indonesia. Indonesian Institute of Sciences (L1PI), Indonesian National MAB Commitee, 41-59.

STR1GEL, G.D, RUHIYAT, D. PRAYITNO AND S. SARMINA. 1993. Nutrient input by rainfall into secondary forests in East Kalimantan, Indonesia. J. Trop. Ecol. 10(2):285-288.

TORQUEBIAU, E.F. 1986. Mosaic pattern in Dipterocarps forest in Sumatra. Agroforestry Systems 2(2):103-128.

TRICHON, V. 1996. Heterogeneite spatiale des structures en foret naturelle de basse a Sumatra, Indonesie. Doctoral de 1'Universite Paul Sabatier. Toulouse, France.

VITOUSEK, P.M AND R.L. SANFORD, JR. 1986. Nutrient cycling in moist tropical forest. Ann; Rev. Ecol. Syst. 17:137-167.

WHITMORE, T.C. 1984. Tropical rain forests of the far east. Clarendon Press, Oxford.

YAMAKURA, T, A. HAGIHARA, S. SUKARDJO, AND H. OGAWA 1986. Aboveground biomass of tropical rain forest stands in Indonesian Borneo. Vegetation 68:71-82 